\title{
Gender Construction of Dayak Benuaq Society in the Novel Api Awan Asap by Korrie Layun Rampan: A Feminist Anthropology Perspective
}

\author{
Furoidatul Husniah ${ }^{1}$, Haris Supratno ${ }^{2}$, Heny Subandiyah ${ }^{3}$, Udjang Pairin ${ }^{4}$, Darni $^{5}$, Suhartono ${ }^{6}$ \\ \{furoidatul.19009@mhs.unesa.ac.id ${ }^{1}$, henysubandiyah@unesa.ac.id ${ }^{3}$, udjangpairin@unesa.ac.id ${ }^{4}$; \\ darni@unesa.ac.id ${ }^{5}$; suhartono@unesa.ac.id ${ }^{6}$ \}
}

Universitas Negeri Surabaya, Surabaya, Indonesia ${ }^{123456}$

\begin{abstract}
This article aims to interpret and describe the gender construction of the Benuaq Dayak community, focusing on the roles of men and women as depicted in Korrie Layun Rampan's novel entitled Api Awan Asap. The novel told a story about the life of Dayak Benuaq people who were still strongly preserving culture which functions as a control mechanism in their lives. This study used a feminist anthropological approach to examine gender relation and its construction in the Dayak Benuaq community. The method it used was interpretive ethnography. The results of the analysis showed that the roles of women and men in Dayak Benuaq community were complement each other. This was based on the democratic value and the feeling of having same fate in both the productive and reproductive field.
\end{abstract}

Keywords: Gender Construction, Benuaq Dayak, Feminist Anthropology.

Konstruksi Gender Masyarakat Dayak Benuaq dalam Novel Api Awan Asap Karya Korrie Layun Rampan: Perspektif Antropologi Feminis

\begin{abstract}
Abstrak. Tulisan ini bertujuan untuk menafsirkan dan mendeskripsikan konstruksi gender masyarakat Dayak Benuaq, dengan menitikberatkan pada peran laki-laki dan perempuan sebagaimana digambarkan dalam novel Api Awan Asap karya Korrie Layun Rampan. Novel tersebut berkisah tentang kehidupan masyarakat Dayak Benuaq yang masih kuat dalam melestarikan budaya yang berfungsi sebagai mekanisme kontrol dalam kehidupan mereka. Studi ini menggunakan pendekatan antropologi feminis untuk mengkaji relasi gender dan konstruksinya dalam masyarakat Dayak Benuaq. Metode yang digunakan adalah etnografi interpretif. Hasil analisis menunjukkan bahwa peran perempuan dan laki-laki dalam masyarakat Dayak Benuaq saling melengkapi. Hal ini dilandasi oleh nilai-nilai demokratis dan senasib sepenanggungan baik dalam ranah produktif maupun reproduktif.
\end{abstract}

Kata kunci: Konstruksi Gender, Dayak Benuaq, Antropologi Feminis 


\section{Pendahuluan}

Karya sastra tidak lahir dari kekosongan budaya. Oleh karena itu, karya sastra yang baik tentunya mampu menggambarkan bagaimanakah sebuah masyarakat dan kebudayaannya. Banyak pengarang menulis tentang kebudayaan dan masyarakatnya; salah satunya Korrie Layun Rampan, seorang penulis asal etnik Dayak Benuaq. Benuaq adalah salah satu suku Dayak yang mendiami pedalaman Kabupaten Kutai, Kalimantan Timur, terutama di Kecamatan Damai, Barong Tongkok, Melak, Lawa, Panyinggahan, Muara Muntai, Kenohan, Muara Pahu, dan Tenggarong. Korrie lahir di Samarinda, Kalimantan Timur, dan tinggal di daerah Kutai Barat [1]. Sebagai seniman besar, Korrie menjadi warga Dayak yang berprestasi karena telah mengangkat harkat dan derajat suku Dayak dalam kancah sastra Indonesia.

Salah satu novel Korrie, berjudul Api Awan Asap (AAA), menggambarkan sebuah kehidupan sosial masyarakat suku Dayak dalam melestarikan alam dengan merawat hutan Kalimantan Timur. Menjaga kelestarian alam adalah adat istiadat turun-temurun yang sudah dilakukan oleh nenek moyang Dayak Benuaq.

Novel AAA juga menggambarkan berbagai aspek kehidupan masyarakat Dayak Benuaq, mulai dari kepercayaan masyarakat terkait mitos memindahkan lou saat terjadi musibah, interaksi sosial, ekonomi, dan kesenian masyarakat, hingga pemeliharaan dan hukum masyarakat. Termasuk di dalam sistem kehidupan tersebut adalah norma-norma yang mengatur peran laki-laki dan perempuan dalam suatu tradisi yang mengajarkan bahwa hidup bersama lebih banyak memberi manfaat daripada hidup perorangan atau mementingkan diri sendiri. Hal ini sesuai dengan konsep kebudayaan sebagai seperangkat mekanisme kontrol, meliputi rencana-rencana, resep-resep, aturan-aturan, instruksi-instruksi untuk mengatur tingkah laku [2].

Dalam novel AAA juga dideskripsikan peran laki-laki dan perempuan Dayak Benuaq yang menjadi pelaku aktif dalam menghidupi kebudayaan mereka. Oleh karena itu, permasalahan gender menjadi hal yang menarik di dalam novel ini. Laki-laki dan perempuan Dayak Benuaq memiliki peran yang dikonstruksi secara sosial budaya oleh masyarakatnya. Konsep "senasib sepenanggungan" menjadi nilai utama dalam bertingkah laku bagi masyarakat Dayak Benuaq. Pembagian peran dalam ranah publik dan domestik antara lakilaki dan perempuan dalam novel AAA menggambarkan kemandirian untuk bertahan hidup dalam konteks berwirausaha dan mengatur perekonomian keluarga.

Gambaran peran laki-laki dan perempuan dalam kebudayaan khas masyarakat Dayak Benuaq menarik jika dikaji dengan pendekatan antropologi feminis. Antropologi feminis menyatukan antara studi tentang gender dengan konstruksinya pada masyarakat yang beragam. Yang menjadi perhatian dalam kajiannya tidak saja perempuan, tapi juga laki-laki, dengan berfokus pada peranan, status, dan kontribusi perempuan dalam masyarakat. Hal ini bukan untuk menunjukkan etnosentrisme ataupun keanehan suatu budaya, melainkan keunikan masing-masing budaya [3]. Hal ini sejalan dengan kritikan para feminis terhadap antropologi sosial yang muncul akibat adanya pengabaian terhadap kajian perempuan dalam disiplin ilmu tersebut. Antropologi feminis yang baru dimulai pada awal tahun 1970-an mengonfrontasikan masalah-masalah representasi perempuan dalam penulisan antropologi. Masalah yang menjadi sorotan adalah adanya tiga tingkatan bias laki-laki (androgenic bias) yang mewarnai kerja para antropolog dalam melakukan penelitian lapangan, yakni bias yang berasal dari para antropolog, bias dari kelompok masyarakat yang diteliti, dan bias yang melekat dalam kebudayaan Barat [4].

Sejalan dengan pendapat di atas, selama ini konstruksi gender patriarkal banyak menimbulkan ketidakadilan gender, salah satunya subordinasi yang menggambarkan peran 
dan posisi perempuan lebih rendah dibandingkan peran dan posisi laki-laki baik dalam keluarga, rumah tangga, ataupun sektor publik. Perempuan selalu berada dalam sektor domestik, sementara laki-laki sangat leluasa dalam sektor publik. Dalam tulisan ini, akan dibahas konstruksi gender terkait peran laki-laki dan perempuan dalam novel Api Awan Asap (AAA) yang didasarkan pada keunikan budaya masyarakat Dayak Benuaq.

\section{Metode}

Studi ini metode etnografi interpretif. Teknik pengumpulan data yang digunakan dalam penelitian ini adalah studi kepustakaan, wawancara, dan diskusi kelompok terfokus (focus group discussion). Studi kepustakaan dilakukan dengan mengumpulkan data dari sumber tertulis yang membahas atau berkaitan dengan gender dan budaya masyarakat Dayak Benuaq. Wawancara dilakukan untuk mencari informasi terkait peran perempuan dan laki-laki Dayak Benuaq sebagaimana digambarkan dalam novel AAA. Wawancara dilakukan dengan dua informan dari Dayak Benuaq melalui telepon dan aplikasi WhatsApp. Adapun analisis data dalam penelitian ini dilakukan melalui tiga tahapan. Pertama, meninjau kembali data hasil penelitian. Kedua, menginterpretasikan data. Ketiga, menyimpulkan hasil penelitian.

\section{Hasil dan Pembahasan}

Konstruksi gender membuahkan perbedaan antara laki-laki dan perempuan. Oleh karena proses sosialisasi dan rekonstruksi yang berlangsung secara mapan dan lama, akhirnya sulit dibedakan apakah sifat-sifat gender tersebut. Dari hasil konstruksi ini, muncul pembagian peran dan kerja antara laki-laki dan perempuan [5]. Dalam novel AAA dibahas tentang konstruksi gender berdasarkan kebudayaan dalam masyarakat Dayak Benuaq di Lou Dempar. Kebudayaan sebagai mekanisme kontrol mengatur peri kehidupan masyarakat Dayak Benuaq. Konstruksi gender tergambar dalam peran laki-laki dan perempuan sebagaimana akan didiskusikan pada bagian berikut.

\subsection{Konstruksi Gender Masyarakat Dayak Benuaq dalam Budaya\sebagai Rencana- Rencana pada Novel AAA}

Budaya sebagai manifestasi berpikir, berisi seperangkat rencana yang dijadikan dasar oleh manusia dalam bereaksi terhadap berbagai problematika kehidupan mereka. Di sinilah letak eksistensi budaya sebagai mekanisme kontrol perilaku manusia yang berisi rencana-rencana dalam wujud gagasan-gagasan atau ide-ide. Dengan kecerdasan intelektualnya, perempuan Dayak Benuaq bukan hanya memberikan ide-ide cemerlang, melainkan juga berperan aktif menghadirkan solusi dalam menghadapi permasalahan yang mereka hadapi. Hal ini tergambar dalam novel AAA dengan kecerdasan intelektual salah satu tokohnya, Nori, yang mampu memberikan solusi bagi warga Lou Dempar dalam menghadapi permasalahan ekonomi yang diakibatkan oleh kondisi kebakaran hutan yang meluas. Sosok perempuan yang cerdas dan berkontribusi dalam membangun desa juga tergambar dalam novel AAA. Tokoh Nori memiliki peran luar biasa dalam membangun desa. Ide-ide cemerlangnya membawa 
perubahan atas keterpurukan warga Lou Dempar. Nori adalah perempuan Dayak Benuaq yang cerdas dan berpendidikan. Ia adalah anak dari tokoh masyarakat yang bernama Petinggi Jepi. Ketika warga menghadapi kebakaran hutan, Nori memotivasi mereka untuk tidak hanya mengandalkan hutan sebagai sumber penghidupan. Nori mengajarkan mereka beternak ayam, menyiapkan mesin tetas, bahkan memasarkan hasilnya ke pasar-pasar. Kecerdasan Nori dalam memberikan pengertian dan penyuluhan, akhirnya menghadirkan secercah harapan. Dalam kondisi terpuruk, Nori mampu berpikir cerdas untuk bangkit meningkatkan ekonomi masyarakat Dayak Benuaq.

Perempuan dapat berpikir rasional, dan ketika kondisi membutuhkan, perempuan mampu melakukan sesuatu untuk mewujudkan perubahan. Hal tersebut menghadirkan hubungan sosial yang harmonis di kalangan warga Dayak Benuaq, baik laki-laki maupun perempuan, hingga mewarnai relasi gender yang berkaitan dengan peran publik dalam hubungannya dengan kekuasaan dan status. Kekuasaan dalam hal ini diidentifikasi dengan aktivitas, kekuatan, penyelesaian, dan pemikiran yang efektif serta dihasilkan melalui kekayaan atau status sosial untuk mencapai tujuan. Indikator tersebut ada pada diri Nori. Dalam konteks tanggung jawab bersama untuk menjaga kelestarian hutan dan kemakmuran masyarakat Dayak Benuaq, kecerdasan intelektual seorang perempuan menjadi solusi bagi permasalahan desa Lou Dempar.

\subsection{Konstruksi Gender Masyarakat Dayak Benuaq dalam Budaya sebagai Aturan- Aturan pada Novel AAA}

Sebagai mekanisme kontrol yang mengatur perilaku manusia, kebudayaan berisikan aturan-aturan, norma-norma, dan nilai-nilai yang dijadikan milik bersama dan pedoman setiap anggota masyarakat dalam berinteraksi. Nilai senasib sepenanggungan memiliki makna perasaan yang sama karena merasakan nasib yang sama. Mereka akan mencari cara untuk menghadapi permasalahannya, sehingga membutuhkan orang lain untuk membantunya. Hal ini tampak dalam kegiatan bergotong-royong membangun lou, rumah panjang suku Dayak.

Lou menjadi ajang asal semua warga. Di dalam lou, semua warga terikat dalam komunitas yang menjalin mereka, sehingga mampu seperasaan dan sepenanggungan. Lou dibangun atas tradisi bahwa hidup bersama memberi manfaat yang lebih besar daripada hidup orang perorangan yang hanya mementingkan diri sendiri. Sistem sosiologis lou ditampilkan melalui bentuk rumah lou yang dibuat sedemikian rupa agar orang-orang yang tinggal di dalamnya merasa aman. Lou juga menjadi tempat pewarisan tradisi, baik berupa kesenian maupun produk budaya lainnya, serta tempat meneruskan garis keluarga. Secara filosofis, lou menunjukkan sistem kekerabatan dan keeratan perasaan di antara masyarakat [6]. Tradisi ini menjadi pedoman dalam bertingkah laku, terutama dalam membangun relasi gender yang tidak membedakan jenis kelamin pada saat menarik pohon-pohon ulin untuk membangun lou. Dalam budaya masyarakat Dayak Benuaq, laki-laki dan perempuan bekerja sama, merasakan senasib sepenanggungan, membangun lou sebagai simbol kebesaran suku mereka. Perempuan dan laki-laki membangun Lou Dempar dengan menarik pohon-pohon ulin bersama-sama. Perempuan juga menyiapkan makanan untuk makan bersama. Hal ini sesuai dengan hasil wawancara dengan salah satu informan yang merupakan perempuan Dayak Benuaq [7].

Selain senasib sepenanggungan, terdapat nilai lain yang diajarkan kepada masyarakat oleh ketua adat Dayak Benuaq. Dalam novel AAA digambarkan, secara psikologis Nori membutuhkan kebahagiaan sebagai istri meskipun suaminya dikabarkan telah meninggal. Di 
tengah kekukuhannya untuk memegang teguh prinsip kesetiaan dalam sebuah perkawinan, dia mampu meluangkan dan membagi waktu untuk memberdayakan para perempuan sebagai istri dan juga para suami untuk bertahan hidup. Dalam mendidik anaknya, Petinggi Jepi, ayah Nori, menanamkan nilai demokratis, berpikir rasional, dan tidak tergesa-gesa mengambil keputusan. Dalam menentukan pasangan, Norilah yang memutuskan untuk menerima atau menolak. Sebagai ayah, Petinggi Jepi tidak memaksakan kehendak dalam menentukan nasib anak perempuannya, karena yang menjalani hidup tersebut adalah putrinya.

Nilai demokratis, berpikir rasional, dan tidak tergesa-gesa mengambil keputusan telah ada dan tertanam dalam masyarakat Dayak Benuaq. Oleh karena itu, konsep patriarki tidak berlaku pada masyarakat Dayak Benuaq. Sosok ayah yang memiliki otoritas atas perempuan, anak-anak, dan harta benda tidak tergambar dalam novel AAA. Nilai ini berlaku dalam peri kehidupan masyarakat Dayak Benuaq sebagai nilai budaya yang dijadikan aturan atau pedoman hidup dalam bertingkah laku. Nilai demokratis dan senasib sepenanggungan mendasari peran gender dan kontribusi perempuan dalam masyarakat Dayak Benuaq.

\subsection{Konstruksi Gender Masyarakat Dayak Benuaq dalam Budaya sebagai Resep-Resep pada Novel AAA}

Budaya sebagai resep-resep merupakan pola pengetahuan yang berkaitan dengan caracara terbaik untuk melakukan sesuatu atau untuk menyelesaikan suatu masalah. Para perempuan suku Dayak Benuaq selain berperan dalam kegiatan reproduktif, juga aktif dalam sektor produktif. Pembedaan peran antara perempuan dengan laki-laki umumnya ada tiga, yaitu dalam kegiatan produktif, reproduktif, dan sosial [8]. Dari ketiga jenis kegiatan tersebut, yang bersinggungan secara langsung dengan internal rumah tangga adalah kegiatan produktif dan reproduktif.

Dalam budaya patriarki, beban pekerjaan yang diterima perempuan lebih banyak dibandingkan laki-laki, sehingga ada upaya lelaki untuk melakukan dominasi terhadap perempuan. Hal yang berbeda tergambar dalam novel AAA. Setelah selesai bekerja, para perempuan berkumpul, berbicara dari hati ke hati tentang mengurus diri supaya tetap cantik, atau tentang bagaimana melayani suami dan mengurus rumah tangga. Dalam hal ini tergambar peran reproduktif perempuan. Peran reproduktif perempuan sering kali dianggap berada di wilayah domestik. Adapun peran produktif mereka terekspresikan dalam keahlian menganyam tikar, tas, dompet, berbagai peralatan dapur, dan mainan anak-anak. Dengan demikian, para perempuan Dayak Benuaq berbagi peran kerja dengan para lelaki. Peran domestik atau reproduktif dilakukan oleh para perempuan Dayak Benuaq sebagai bentuk tanggung jawab sepenuhnya sebagi istri yang mengurus rumah tangga, sementara peran produktif dengan menjual hasil kerajinan tangan mereka lakukan dengan rasa senang, sekaligus untuk memenuhi kebutuhan berekspresi-menganyam dan menenun merupakan bagian dari pelestarian seni tradisi khas masyarakat Dayak Benuaq. Di saat yang bersamaan, kesadaran para perempuan untuk melakukan tugas produktif tidak lantas membuat para lelaki melepaskan tanggung jawab. Sebagai suami, mereka bertanggung jawab bekerja dan memiliki peran produktif.

Para suami, selepas bekerja di huma, pada malam hari memahat dan mengukir, menempa, dan membuat perahu. Biasanya sehabis kembali dari huma untuk memancing atau mengangkat bubu, mereka menekuni pahatan atau ukiran. Berbagi beban atau tanggung jawab dalam konteks produktif menggambarkan nilai budaya senasib sepenanggungan. Senasib sepenanggungan menjadi aturan dalam peri kehidupan masyarakat Dayak Benuaq tanpa 
merugikan kaum perempuan. Hal ini juga disampaikan oleh informan kedua. Berdasarkan hasil wawancara, kedua informan memiliki pendapat yang sama tentang peran laki-laki dan perempuan, di mana dalam ranah domestik maupun publik tidak ada batasan yang jelas di antara kedua jenis kelamin. Kecuali dalam tugas upacara adat, di mana perempuan bertugas menyiapkan sajian yang digunakan dalam upacara, sehingga terdapat pembedaan jenis pekerjaan di antara kedua jenis kelamin [9].

\subsection{Konstruksi Gender Masyarakat Dayak Benuaq dalam Budaya sebagai Petunjuk pada Novel AAA}

Budaya juga dapat diibaratkan sebagai kompas yang berisi petunjuk-petunjuk yang mengarahkan manusia untuk senantiasa menggunakan akal budinya dalam bertindak sehingga selalu berada pada jalur yang tepat dalam hidup bermasyarakat. Terkait hal ini, tata cara pelamaran dalam masyarakat Dayak Benuaq sebagaimana digambarkan novel AAA menunjukkan bahwa di dalam tradisi mereka tidak ada pembedaan antara pria dan wanita. Lamaran dapat dilakukan oleh pihak pria maupun wanita. Yang membedakan ketika wanita melamar terlebih dahulu atau laki-laki melamar terlebih dahulu adalah hantaran yang dibawa. Selain itu, pembedaan lebih disebabkan oleh status sosial yang melekat pada pihak perempuan dan pihak laki-laki. Dalam novel AAA, hal ini digambarkan melalui kasus Nori (perempuan) dan Sakant (laki-laki), di mana keduanya memiliki posisi yang berbeda dalam masyarakat Dayak Benuaq. Nori merupakan putri Petinggi Jepi, sementara Sakant adalah teman Jue (suami Nori), laki-laki berpendidikan dan ternama. Hal ini menunjukkan bahwa relasi laki-laki dan perempuan dalam ritual-ritual dan upacara distratifikasi berdasarkan status sosial dan prestasi (personal achievement), bukan berdasarkan gender.

Hal ini sesuai dengan salah satu dari dua klasifikasi kepulauan di Asia Tenggara berdasarkan ideologi gender dan kekuasaan pada masing-masing budaya, sebagaimana didiskusikan dalam buku Power and Difference, yakni centrist archipelago, yang terdiri atas Malaysia, sebagian Jawa, Kalimantan, Sulawesi, dan Filipina. Menurut Errington, pada daerah-daerah yang dianggap centrist archipelago tersebut, perbedaan gender cenderung ditampilkan dalam ritual, ekonomi, dan pakaian. Mereka cenderung menganut sistem kekerabatan bilateral, di mana laki-laki dan perempuan dianggap saling melengkapi atau komplementer, bahkan makhluk yang identik (identical beings) pada banyak hal [8].

\section{Simpulan}

Antropologi memandang tiap-tiap budaya memiliki keunikan tersendiri. Oleh karena itu, hal yang berkaitan dengan relasi gender akan berbeda pada tiap-tiap budaya dan tidak bisa digeneralisasikan - dengan kata lain, gender dikonstruksi sesuai konteks budaya yang spesifik. Terkait relasi gender, dalam novel AAA terlihat bahwa relasi laki-laki-perempuan pada masyarakat Dayak Benuaq dikonstruksi berdasarkan nilai budaya senasib sepenanggungan. Hal ini terlihat dalam kegiatan membangun Lou sebagai simbol kebesaran dan kebersamaan masyarakat Dayak Benuaq. Laki-laki dan perempuan juga berbagi peran produktif, reproduktif, dan sosial. Nilai kemandirian dan demokratis juga tertanam pada diri perempuan Dayak Benuaq, sehingga mampu berkontribusi dalam kehidupan masyarakatnya. Artinya, 
konstruksi gender dalam masyarakat Dayak Benuaq menampilkan relasi gender yang diwarnai pengejawantahan peran laki-laki dan perempuan yang saling bekerja sama dan melengkapi.

\section{Referensi}

[1] Korrie Layun Rampan. “Api Awan Asap”. Jakarta: Penerbit PT Grasindo. 1999

[2] Clifford Geertz. "Tafsir Kebudayaan”. Yogyakarta: Kanisius. 1992

[3] Nurul Ilmi Idris . "Antropologi Feminisme: Etnografi Relasi Gender dan Relativisme Budaya di Indonesia”. Pidato Pengukuhan Guru Besar. Universitas Hasanuddin Makassar. 14 September 2006.

[4] Moore, H. "Feminism and Anthropology". Oxford: Polity Press. 1988

[5] Fakih Mansor. "Analisis Gender dan Transformasi Sosial”. InsistPress.2016

[6] Dian Kurniawati. "Sistem Lou Dan Huma Dalam Masyarakat Dayak Benuaq: Membaca Novel Api Awan Asap Karya Korrie Layun Rampan”. Aksara.kemendikbut.go.id. (diakses 12 Mei 2020). 2019

[7] Erny Rading. Wawancara. 26-27 Oktober 2020.

[8] Y. Yuliati. "Perubahan Ekologis dan Strategi Adaptasi Masyarakat di Wilayah

[9] Pegunungan Tengger: Suatu Kajian Gender dan Lingkungan”. Malang: UB Press. 2011

[10] Riski. Wawancara. 27 Oktober 2020

[11] S. Errington, "Recasting Sex, Gender, and Power: A Theoretical and Regional Overview," dalamJane M. Atkinson and Shelly Errington (peny.) 'Power and Difference: Gender inIsland Southeast Asia. California”: Stanford University Press. Hlm. 1-58. 1990. 